Andrzej Dembicz

\title{
AN ATTEMPT AT A NEW CLASSIFICATION OF PLANTATIONS
}

One of many controversial points in geography has been for a long time the issue of plantations as a kind of productive activity and a pattern of social and economic organization of rural areas. The argument is not exclusive for geography but it has also been present in other disciplines, such as ethnology, economy, history or sociology. The discussion on plantations abandoned about 1950 the definition course to pass to the sphere of the problems of time and spatial dynamics, therefore to classification of plantations. If, however, the investigators in the previous stage focused their attention on internal features and the mechanism of plantation functioning, during the attempts at a classification, non-agricultural features of plantations and their external links were often taken into consideration. It appears that the majority of investigators wanted to see piantations first of all as a link of a larger chain of social and economic structures without earlier penetration of their internal structure, i.e. their differentiation.

In effect, after many scores of years of studies there predominate classifications based first of all on separation of big socio-economic formations, i.e. slavery-capitalism-socialism. Good examples may be propositions of E. Wolf ${ }^{1}, \mathrm{R}$. Crist ${ }^{2}$, or M. Prunty $\mathrm{Jr}^{3}$ or one of the latest suggestions of P.R. Scott. ${ }^{4}$ An interesting attempt at avoiding time

1 Wolf, E., „Aspectos especificos de sistema de plantaciones en el Nuevo Mundio: comunidad, subculturas y clases sociales" in: Sistema de plantaciones en el Nuevo Moundo, Unión Panamericana, Washington DC 1964, pp. 160-171.

"Crist, R.E., "Cultural Dichotomy in the Island of Hispaniola", Economic Geography 28, 1952, pp. 105-121.

3 Prunty, M. Jr., "The Renaissance of the Southern Plantation”, Geographical Review 45, 1955, pp. 459-491.

${ }^{4}$ Scott, P. R., "Group Identification as an Adaptation to Modernization in Brazil", in: Bendichevsky, B. (ed.), Anthropology and Social Change in Rural Areas, The Hague-Faris-New York 1979, pp. 364-381. 
dichotomy was undertaken by B. W. Higman ${ }^{5}$, who took as a basis for classification relations between the agricultural and processing sectors of a sugar cane plantation, although he obtained a division of rurai functional space rather than classification of plantations.

In effect, although undoubtedly significant progress has taken place in the cognitive sphere, not too big progress has been made in the sphere of synthetic arrangement of plantations since the times of $F$. Ortiz and $R$. Guerra. As early as at the beginning of the 20th century they classified Cuban sugar cane plantations, distinguishing the following types: 1. Slave plantations, 2. Capitalist plantations and among them: (a) independent sugar cane estates (colonias independientes), (b) leasehold sugar cane estates (colonias dependientes or contratadas) and (c) integral plantations (caña de administración).

Apart from that, the majority of the proposed models of time and spatial dynamics of plantations has non-argicultural character and thus they are not suitable to evaluate the activity which is in substance agricultural.

Similarly to the earlier discussed typological classifications of agriculture, there appears the issue of comparability and objectivity of the input data. Such criteria and parameters create posslibilities for intellectual speculations; they do not allow one, however, to obtain verifiable and comparaible results. In order to make a step forward it is necessary to take into consideration agricultural and quantitatively measurable criteria. These conditions are met by the method of typology of agriculture worked out by J. Kostrowicki. It has not been applied so far to studies on plantation agriculture. The method was made public in publications of the I. G.U. Typology Commission so there is no need to discuss it in detail ${ }^{6}$.

The final version of the method based on 27 variables was applied The attempt at a new classification of plantations presented here is based on empirical material taken from sugar cane agriculture of Cuba; nonetheless the intention is to distinguish a group of types with universal application (first of all to sugar cane plantations, and broader-to plantation agriculture in general).

The following definition of plantation was accepted as the point of reference: „Plantation is a supra-family agricultural enterprise, cen-

${ }^{5}$ Higman, B.W., "Plantations and Typological Problems in Geography” The Australian Geography 11, pp. 1912-203.

${ }^{6}$ The bibliography on the subject as weil as a synthesis of activities of the commission are presented in Kostrowicki, J., "Twelve Years' Activity of the IGU Commission on Agricultural Typology", Geographia Polonica 40, 1979, pp. 235-253 . 
trally managed and specialized in production of vegetable produce obtained from perennial and semiperennial crops, conducted with application of suitable, uniform methods and using possibly full or partial industrial processing of the produce in order to obtain marketable products". Such a notion of plantation is applicable to various epochs of social and economic development.

The period of research covers the years $1827-1975$ and the analysed material consists of cases of individual agricultural estates (altogether 253 cases for the whole studied period) specialized in sugar cane cultivation (or cultivation and processing) in seven selected time profiles: 1827, 1860,1913,1946, 1964, 1970 and 1975. The data for the years 1964, 1970 and 1975 come from regional studies conducted in the area of sugar cane cultivation, mainly in western and central Cuba.

Typological procedure allowed us to classify Cuban agriculture specialized in commercial sugar cane cultivation under 9 types.

\section{TIME PROFILES 1827 AND 1860}

(1) Slave, medium-scale farm with mixed semi-subsistence agriculture and commercial cultivation and processing of sugar cane (Lnt)? This type was identified in 1827 in Puerto Rico and in 1860 in Cuba. These farms functioned in the majority of cases on the basis of family labour force and seldom on hired labour force employed in activities not connected with sugar cane. Participaton of slaves was insignificant. To a great extent the purpose was subsistence production with a margin for commercial cultivation and processing of sugar cane, commercializing sugar of the lowest class (mascabado or raspadura). It is highly probable that further studies will prove that this type also comprises some sitios de labor with primitive cane mills as well as smali ingenios from the 18th century, i.e. from the initial phase of development of the Cuban sugar economy.

(2) Slave, large-scale highly specialized, productive and commercial, integral (agricultural-processing) sugar cane and sugar estate (Lns). This type was identifeid in both time profiles. It may be considered as the type of a classical sugar cane plantation towards the close of the slavery epoch. Its possible universal, Latin American application was confirmed by the studied cases in Jamaica and Puerto Rico. Cuban investigators define plantations of this type as "mechanized plantations" or "semi-mechanized plantations". During the last years of their oc-

i Letter symbols correspond to the principles accepted in the method of agriculture typology. 
currence in Cuba they adopted some features characteristic of early capitalism, such as e.g. increase in participation of free labour force resulting from technological modernization and importation of Chinese temporary workers.

(3) Slave, large-scale, peripheral and extensive integral sugar cane and sugar estate with substantial participation of marketable stock-breeding activities (Lna). This type was identified in 1860 although, as it appears from its characterictics, it is almost certain that it must have cccurred also at the beginning of the 19th century. Its social and organization-technical features are similar to the previous type although it is more extensive and has a substantial participation of stock-breeding which can be seen in the share of pastures (over $60 \%$ ) and the share of animal products in the value of total production $(20-40 \%)$. Simultaneously, the share of sugar in the total production is smaller although sugar was most often the only commercialized article. This type based on abundant land resources developed exlusively in peripheral areas: in eastern peripheries, in pre-cane areas which later on experienced rapid expansion of sugar cane-sugar economy in the 20th century, and in post-cane areas, on the land tired with long cultivation of sugar cane.

TIME PROFILES 1913--1975

(1) Large-scale (latifundian) extensive estate, highly specialized in commercial sugar cane production (or production and processing) (Lps). This type was identified in 1913 and 1946 mainly among integral, agricultural-procéssing plantations. It also represents large proprietary and leasehold sugar cane estates, mainly from eastern provinces of Camagüey and Oriente, ranging between 100 and 1,000 ha. of agricultural land.

Those plantations were the effect of strong tendencies to turn the sugar cane-sugar complex of Cuba into latifundia. Concentration of land in those estates caused the creation of reserves of land. Usually, no more than $50 \%$ of the arable land of the plantations was used to cultivate sugar cane. The cultivation was conducted with application of traditional methods and techniques. From the point of view of infractructure, an important role was played by the network of sugar cane railways enabling to control the economically large territories. Specialization of production was very high and sugar cane was the only commercialized product.

(2) Large-scale farm with extensive agriculture specialized in commercial production of sugar cane and with substantial participation of 
$\therefore$

Table 1

Selected Quantitative Parameters of Sugar Cane Plantations of the Slavery Epoch

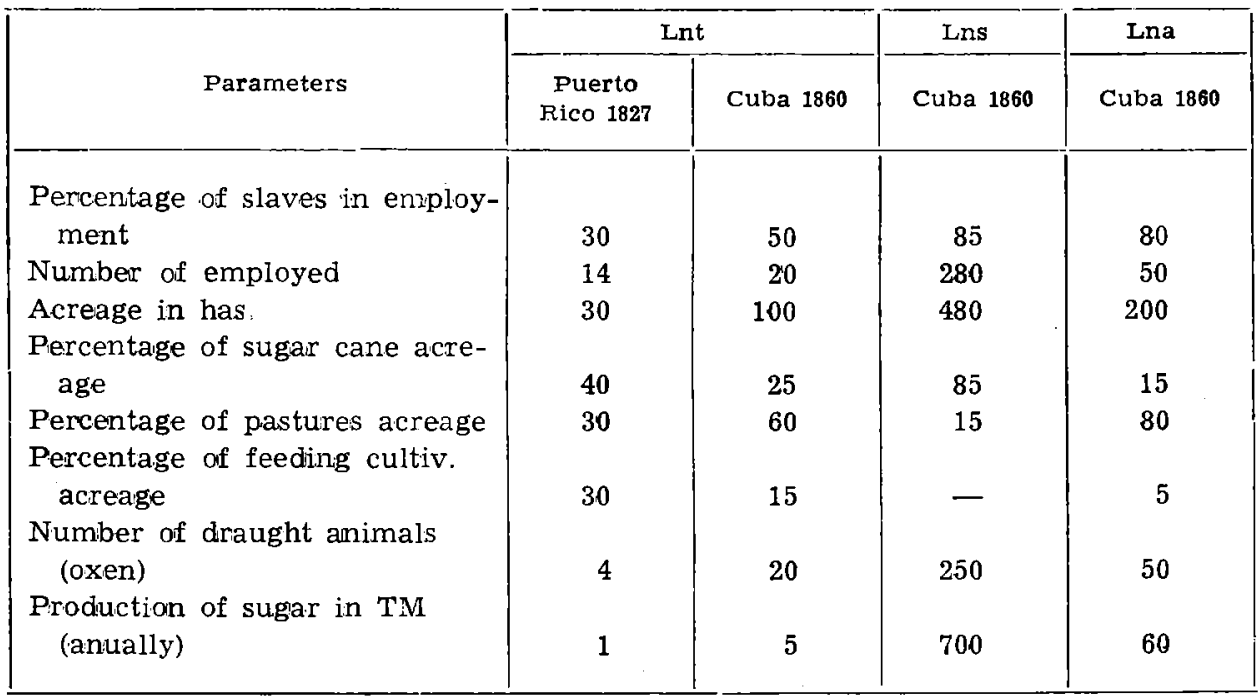

The examples have been taken from among the studied units

traditional stock-breeding (Lpa). This type was identified in 1946 and in 1964 as a transitional type from „Lpm”. Those were usually farms of over 50 ha. of agricultural land existing in the areas of strong stock-breeding traditions. From the point of view of land use, their basic activity was stock-breeding (60-90 per cent of pastures), although done by traditional methods and based on herds of inferior quality which in effect gave no more than 35-per cent share of stock-breeding in the total production. The basic commercial product was sugar cane providing 40-60 per cent of commercial production.

This type may be considered a continuation of the previously described type „Lna”, existing in the slavery epoch.

(3) Medium-scale farm with extensive agriculture highly specialized in commercial production of sugar cane (Lpm). It was identified in 1913, 1946 and 1964. This is the type representing proprietary or leasehold sugar cane farm existing in Cuba until 1959, and after 1959 -farms of small individual farmers. Most often the acreage of those farms ranged from 20 to 75 ha. They applied extensive methods of cultivation, with medium productivity (yield of 20-40 tons of sugar cane per 1 ha.) but with a high degree of commercialization and specialization in marketable produce. Sugar cane usually does not exceed 50 per cent of the acreage. 
(4) Medium-scale farm highly specialized in intensive, commercial production of sugar cane (Mss). It was identified in 1946, 1964 and 1970/75. Those are farms usually not exceeding 100 ha., highly specialized in production of sugar cane, cultivated by modern methods and techniques of production with application of mechanization and chemization. Their productivity is high or very high (yield usually over 40 tons per 1 ha.). Degree of commercialization is very high and the only commercialized product is sugar cane. The share of sugar cane cultivation in the acreage of arable land is over $60 \%$, and in the total production above $80 \%$.

Before the revolution this type of farms began to appear in the 1940 s, although it was not very common until 1959. In the process of restructuring of agriculture and sugar economy after 1968 , the majority of individual farms evolved in the direction of this type, most often from „Lpm”.

(5) Large-scale, socialized farm with mixed agriculture dominated by commercial production of sugar cane (Ssc). It was identified in 1964 . Immediately after the revolution as a result of nationalization of land and attempts at abandoning sugar cane monoculture, large farms with

Table 2

Selected Quantitative Parameters of Sugar Cane Plantations in the Years 1913, 1946 and 1964

\begin{tabular}{|c|c|c|c|c|c|c|}
\hline \multirow[b]{2}{*}{ Parameters } & \multirow{2}{*}{$\frac{L p s}{1913}$} & \multicolumn{2}{|c|}{$L p m$} & \multicolumn{2}{|c|}{ Mss } & \multirow{2}{*}{$\frac{L p a}{1946}$} \\
\hline & & 1946 & 1964 & 1946 & 1964 & \\
\hline Number of employed & 500 & 27 & 9 & 32 & 6 & 5 \\
\hline Acreage in ha. & 2.492 & 180 & 17 & $17 \overline{5}$ & 67 & 130 \\
\hline $\begin{array}{l}\text { Percentage of sugar } \\
\text { cane }\end{array}$ & 45 & 63 & 47 & 82 & 57 & 17 \\
\hline $\begin{array}{l}\text { Percentage of pastures } \\
\text { acreage }\end{array}$ & $5 \overline{5}$ & 33 & 47 & 15 & 36 & 70 \\
\hline $\begin{array}{l}\text { Percentage of feeding } \\
\text { cultiv. acreage }\end{array}$ & - & 4 & 6 & 3 & 7 & 6 \\
\hline $\begin{array}{l}\text { Production of sugar } \\
\text { cane in thousand } \\
\text { tons }\end{array}$ & 70 & 2,6 & 0.4 & 3.7 & 1,5 & 0,6 \\
\hline $\begin{array}{l}\text { Yield of sugar cane in } \\
\text { tons } / 1 \text { ha }\end{array}$ & 65 & 24 & 40 & 28 & 41 & 23 \\
\hline $\begin{array}{l}\text { Mechanical traction } \\
\text { force in HP } 100 \text { ha } \\
\text { of arable land }\end{array}$ & - & 一 & - & 36 & 81 & - \\
\hline
\end{tabular}

The examples have been taken from among the studied units 
mixed agriculture were established. In the zones of co-existence of sugar cane and other cultivations, they were often dominated by sugar cane. They were very large units with modern elements of organization and agrotechny. Sugar cane covered generally $40-60 \%$ of the arable land giving most often about $70 \%$ of the value of total production. Farms of this type were identified in western Cuba. After 1970, this type of sugar cane farms ceased to exist in Cuba being replaced by the highly specialized type ,Sss" described below. (Type „Ssc" was discovered by J. Kostrowicki and used here to describe the behaviour of cases classified under it).

(6) Large-scale, socialized modern farm highly specialized in commercial production of sugar cane (Sss). Economic and organizational reforms realized within the sugar cane-sugar complex from 1968 onwards, have led to the rise of modern, highly productive, large-scale, socialized plantations, extremely specialized also from the point of view of structure of land cultivation. Units of this type were identified in Cuba in 1964 in the east of the country (Oriente, Camagüey) and among empirical materials from 1970 and 1975 from western Cuba. Apart from that, universality of this type was confirmed by including in it a large co-operative plantation of sugar cane in Casa Grande (Peru).

What are the relations between the described types and the model of plantation defined before? There are no doubts that the types of agriculture marked as „Lns”, „Lna”, „Lps” and ,Sss" fully meet the requirements of the set model. The remaining ones are classical exam-

Table 3

Selected Quantitative Parameters of Socialized Sugar Cane Plantations

\begin{tabular}{|c|c|c|c|c|}
\hline \multirow[b]{2}{*}{ Parameters } & \multirow{2}{*}{$\frac{\text { Ssc }}{1964}$} & \multicolumn{2}{|c|}{ Sss } & \multirow[b]{2}{*}{$\begin{array}{l}\text { Casa Grande } \\
\text { (Peru) } 1975\end{array}$} \\
\hline & & $\begin{array}{l}\text { Cuba } \\
1970\end{array}$ & $\begin{array}{l}\text { Cuba } \\
1975\end{array}$ & \\
\hline Number of employed & 2600 & 3100 & 1550 & 3050 \\
\hline Acreage in ha, & 10011 & 16500 & 6600 & 30500 \\
\hline Percentage of sugar cane acr. & 31 & 78 & 88 & 69 \\
\hline Percentage of pactures acr. & 44 & 9 & 5 & 21 \\
\hline $\begin{array}{l}\text { Percentage of feeding cultiv. } \\
\text { acreage }\end{array}$ & 25 & 13 & 7 & 1 \\
\hline $\begin{array}{l}\text { Production of sugar cane in } \\
\text { thousand tons }\end{array}$ & 121 & 1040 & 406 & 22.65 \\
\hline $\begin{array}{l}\text { Yield of sugar cane in tons } / 1 \\
\text { ha. }\end{array}$ & 40 & 80 & 70 & 200 \\
\hline $\mathrm{HP} / 100$ ha of arable land & $8 \overline{5}$ & 200 & 217 & 100 \\
\hline
\end{tabular}

The examples have been taken from among the studicd units 
ples of ambivalent types between: small-scale specialized peasant agriculture and highly specialized, large-scale agriculture (Lpm); socialized mixed agriculture and socialized, highly specialized agriculture (Ssc); or finally (in the case of "Lnt") between suibsistence and commercial agriculture. But each type also comprises, and may be first of all, which was presented in examples, agriculture termed here as plantation. Therefore the types distinguished here allow us to create a full picture of plantation agriculture of sugar cane in Cuba in historical perspective.

Studies on Cuban sugar cane agriculture allowed us to distinguish 8 new types. Previously, J. Kostrowicki separated three types defined as : „Lpt” — traditional latifundian plantations, „Mlp” — modern capitalist plantations which have not been identified in Cuba, and "Ssc", which was used here. Altogether, they make a series of eleven types which, as shown by results of the conducted studies, comprise probably the entire evolution of plantations, not only of sugar cane, in the New World. It seems that this creates new possibilities in studies on socio-economic and functional problems of the rural space, in Latin America at the beginning. The studies thereon will be continued. 